\title{
THE SURVIVAL OF TRANSFUSED ERYTHROCYTES FROM PATIENTS WITH POLYCYTHAEMIA VERA
}

\author{
BY \\ J. S. ELWOOD AND H. E. de WARDENER \\ From the Clinical Laboratories and Department of Medicine, St. Thomas's \\ Hospital Medical School, London
}

(RECEIVED FOR PUBLICATION NOVEMBER 16, 1950)

The following observations are concerned with the survival of erythrocytes from three polycythaemic patients transfused into normal recipients and estimated by the method of differential agglutination.

The donors were (1) a man aged 60 , known to be suffering from polycythaemia vera for seven years. A typical blood count at one time in July, 1949, gave R.B.C. 11.6 million, W.B.C. 19,000 , Hb $112 \%$ (Haldane $100 \%=14.8$ g. $\%$ ), and a haematocrit of 76 ; (2) a man aged 34 , first seen in January, 1949, with the follow-

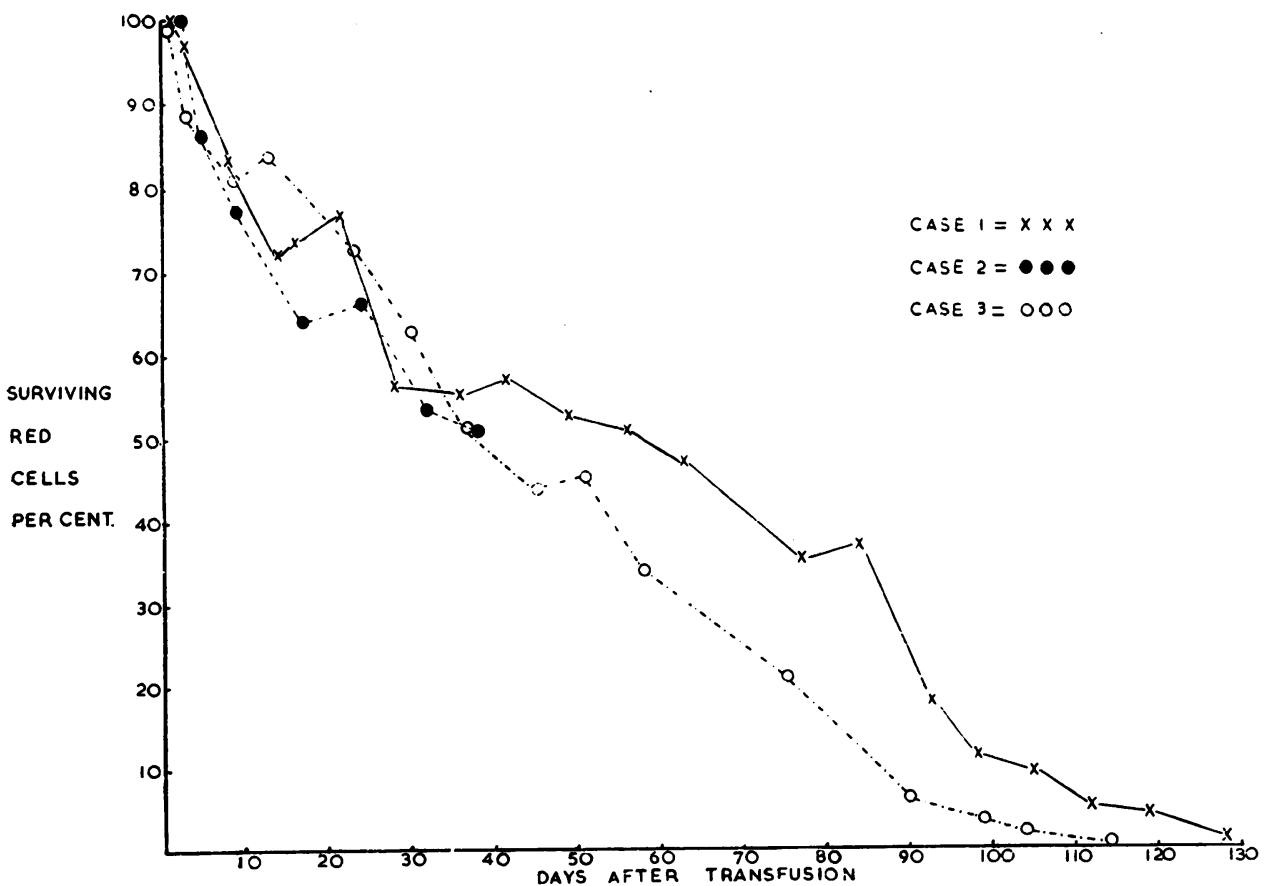

Fig. 1.-Diagram showing survival of cells from cases of primary polycythaemia after transfusion, into normal recipients. 
ing blood count: R.B.C. 11 million, W.B.C. $17,000, \mathrm{Hb} 156 \%$, and a haematocrit of 84 ; (3) a man aged 61, first seen in March, 1950, when he had a blood count of R.B.C. 8.7 million, W.B.C. $81,000, \mathrm{Hb} 126 \%$, haematocrit 58, and was found to have a myelosclerotic bone marrow. This latter association in certain cases of polycythaemia vera has recently been stressed by Dameshek (1950).

The recipients were (1) a normal man, aged 28 ; (2) a man aged 42 , suffering from carcinoma of the bronchus, whose general condition was initially satisfactory, except for a slowly resolving paraplegia due to spinal secondaries ; (3) a woman aged 62 , recovering from a cerebral thrombosis and with mild iron deficiency anaemia. Unfortunately, six weeks after transfusion, the second recipient died from cerebral secondaries, which became manifest four weeks after transfusion.

\section{Technique}

Approximately 1 pint of citrated blood from a polycythaemic donor was transfused after storing for 24 hours into the recipient. The day after transfusion and at intervals thereafter the surviving cells were estimated by differential agglutination, using the ABO system. This was carried out by Dacie's method (1950).

For the purpose of constructing a graph the basal inagglutinable count was subtracted from the inagglutinable count found on any particular day after transfusion. That count on the day after transfusion is called $100 \%$ survival, and the number of surviving cells on subsequent days is expressed as a percentage of this figure.

TABLE I

Survival of Cells from Cases of Primary Polycythaemia after Transfusion into NORMAL RECIPIENTS

\begin{tabular}{|c|c|c|c|c|c|c|c|c|}
\hline \multicolumn{3}{|c|}{$\begin{array}{c}\text { Transfusion from Case } 1 \text { to } \\
\text { Recipient } 1^{*}\end{array}$} & \multicolumn{3}{|c|}{$\begin{array}{c}\text { Transfusion from Case } 2 \text { to } \\
\text { Recipient } 2 \dagger\end{array}$} & \multicolumn{3}{|c|}{$\begin{array}{c}\text { Transfusion from Case } 3 \text { to } \\
\text { Recipient } 3 \ddagger\end{array}$} \\
\hline $\begin{array}{l}\text { Days after } \\
\text { Trans- } \\
\text { fusion }\end{array}$ & $\begin{array}{c}\text { Observed } \\
\text { Count } \\
\text { (c.mm.) }\end{array}$ & $\begin{array}{l}\text { Percent- } \\
\text { age Cells } \\
\text { Surviving }\end{array}$ & $\begin{array}{l}\text { Days after } \\
\text { Trans- } \\
\text { fusion }\end{array}$ & $\begin{array}{c}\text { Observed } \\
\text { Count } \\
\text { (c.mm.) }\end{array}$ & $\begin{array}{l}\text { Percent- } \\
\text { age Cells } \\
\text { Surviving }\end{array}$ & $\begin{array}{l}\text { Days after } \\
\text { Trans- } \\
\text { fusion }\end{array}$ & $\begin{array}{c}\text { Observed } \\
\text { Count } \\
(\text { c.mm. })\end{array}$ & $\begin{array}{l}\text { Percent- } \\
\text { age Cells } \\
\text { Surviving }\end{array}$ \\
\hline $\begin{array}{r}1 \\
3 \\
8 \\
14 \\
16 \\
22 \\
28 \\
36 \\
42 \\
49 \\
56 \\
63 \\
77 \\
84 \\
93 \\
98 \\
105 \\
112 \\
119 \\
128 \\
140\end{array}$ & $\begin{array}{r}570,000 \\
555,000 \\
480,000 \\
417,000 \\
423,000 \\
442,000 \\
328,000 \\
322,000 \\
330,000 \\
306,000 \\
299,000 \\
275,000 \\
210,000 \\
216,000 \\
112,000 \\
75,000 \\
61,800 \\
39,400 \\
36,000 \\
19,400 \\
7,600\end{array}$ & $\begin{array}{r}100.0 \\
97.3 \\
84.0 \\
72.7 \\
73.8 \\
77.1 \\
56.9 \\
55.8 \\
57.4 \\
53.0 \\
51.7 \\
47.4 \\
35.9 \\
37.0 \\
18.4 \\
11.8 \\
9.5 \\
5.5 \\
4.9 \\
1.9 \\
0\end{array}$ & $\begin{array}{r}2 \\
5 \\
9 \\
17 \\
24 \\
32 \\
38\end{array}$ & $\begin{array}{l}480,000 \\
422,000 \\
382,000 \\
325,000 \\
335,000 \\
278,000 \\
267,000\end{array}$ & $\begin{array}{r}100.0 \\
86.7 \\
77.6 \\
64.6 \\
66.9 \\
53.9 \\
51.2\end{array}$ & $\begin{array}{r}1 \\
3 \\
9 \\
13 \\
23 \\
30 \\
37 \\
45 \\
51 \\
58 \\
75 \\
90 \\
99 \\
104 \\
114 \\
119\end{array}$ & $\begin{array}{r}679,000 \\
607,600 \\
558,800 \\
566,400 \\
504,200 \\
447,000 \\
359,000 \\
319,000 \\
326,000 \\
245,400 \\
139,700 \\
59,200 \\
39,200 \\
32,800 \\
19,200 \\
13,400\end{array}$ & $\begin{array}{r}100.0 \\
89.3 \\
81.9 \\
83.1 \\
73.9 \\
63.6 \\
51.9 \\
44.4 \\
45.4 \\
34.7 \\
21.0 \\
6.8 \\
3.8 \\
2.8 \\
0.8 \\
0\end{array}$ \\
\hline
\end{tabular}




\section{Results}

The results are shown in Fig. 1 and Table $I$. The survival of cells from polycythaemic patients was found to be normal in the experiments which were completed. The rate of destruction in the patient who died six weeks after transfusion was also found to be normal.

\section{Summary}

Our observations show that the life span of transfused red cells from cases of primary polycythaemia is normal. These results confirm the findings of Merskey (1949), who used a similar differential agglutination technique. There is further confirmation that the red cell life in primary polycythaemia is normal. Using another technique (with isotopic nitrogen), London, Shemin, West, and Rittenberg (1949) have shown in one case that the otherwise undisturbed red cell in a polycythaemic patient has a normal life span.

We wish to thank Dr. A. E. Mourant for providing us with high titre agglutinating sera.

\section{REFERENCES}

Dacie, J. V. (1950). Practical Haematology. London.

Dameshek, W. (1950). J. Amer. med. Ass., 142, 790.

London, I. M., Shemin, D., West, R., and Rittenberg, D. (1949). J. biol. Chem., 179, 463.

Merskey, C. (1949). S. Afr. J. med. Sci., 14, 1. 